\title{
Knowledge and degree of training of primary education teachers in relation to ICT taught to disabled students
}

\section{José María Fernández-Batanero, Julio Cabero and Eloy López}

José María Fernández-Batanero is an associate professor of the Teaching and Educational Organisation Department of the University of Seville, Spain. His academic interests lie in teacher training in relation to ICT for people with disabilities. Julio Cabero is an emeritus professor of Teaching and Educational Organisation at Seville University, Spain. He is widely known for his work in educational technology and new technologies for education. Eloy López is an associate professor of the Department of Education and Social Psychology at the Pablo de Olavide University of Seville, Spain. His research focuses on Educational Technology, Teaching and Higher Education. Address for correspondence: Professor José María Fernandez-Batanero, School of Education, University of Seville, Seville 41013, Spain. Email: batanero@us.es

\begin{abstract}
The integration of Information and Communication Technologies (ICT) into the inclusive classroom requires competent teaching staff from both the technological and pedagogical points of view. Within this context, and with the aim of looking at one of these theoretical premises, this study aimed to identify the degree of training and technological knowledge of primary school teachers in Spain with respect to the use of ICT with individuals with disabilities (functional diversity). A descriptive ex post-facto research method was used, where the sample comprised 777 teachers. An ad-hoc questionnaire was used as the data-collection instrument. The results revealed the low skill levels of the teachers with respect to the use of ICT with students with disabilities, where the level of training of the teaching staff was determined by personal (gender, age), professional (teaching experience) or educational (qualifications) variables. The findings of this study point to the need for teacher training that instructs teachers on the use of ICT in order to favour the learning and educational innovation of students with disabilities.
\end{abstract}

Keywords: Information and Communications Technology, disability, teacher training, accessibility. 


\section{Introduction}

The transformation and evolution ICT has led to in today's societies have meant that education centres have had to integrate these tools to improve the teaching and learning processes.

At the international level, there are many studies that highlight the importance of the integration of technology to improve the learning of the "entire" student body (Ghaleb, 2014; Hu \& Yelland, 2017...), but there is a scarcity of studies that stress its use with students with disabilities (Istenic \& Bagon, 2013; Hersh, 2016), despite the fact that the United Nations Convention on the Rights of Persons with Disabilities (2006) considers ICT to include key tools for promoting fairness and equal opportunities. In this sense, the potential of ICT to contribute to a better quality of life for students with disabilities, is brought to light. That said, one of the problems we face in ensuring that ICT reaches all students, including those who have a disability, is teacher training, as shown by recent studies (Cappuccio, Compagno \& Pedone, 2016).

According to Hatlevik (2017), among others, teachers feel competent to use ICT as a personal tool and/or resource for the projection and transmission of information and knowledge, without this implying the creation of significant learning, but also show distrust towards the use thereof for didactic purposes. This could be due to the fact that the training model that has been commonly used focusses more on instrument-related aspects than pedagogical ones (Suriá, Martínez \& Ordoñez, 2010; Tello \& Cascales, 2015). In this sense, research on the effectiveness of teacher training and ICT shows that the type of information offered (courses, seminars, etc.), besides being scarce, does not lead to changes in the teaching activity (Hu \& Yelland, 2017).

On the other hand, along with the quality of the training, there are various personal and professional variables that affect the carrying out of training activities such as gender, age, teaching experience, qualifications, attitudes and technological mastery. Along these lines, Suárez, Almerich, Gargallo \& Aliaga (2013) and Ilomäki (2011), attest that the gender and age of teaching staff are factors linked to training in ICT, indicating that teaching staff possess different levels of competencies and where male teachers show a greater level of technological competency while female teachers are more likely to integrate ICT into their teaching practices.

Also, Cabero \& Martín (2014) argue that younger teachers have greater knowledge, and also, Alqurashi, Gokbeli \& Carbonara (2017), Gudmundsdottir \& Hatlevik (2017) indicate that the recently-qualified (recent graduates) feel more confident about integrating this technology.

In accordance with the above, if the teacher's level of ICT training is scarce or inefficient, the studies that deal with the active teacher's ICT training and the use thereof with the disabled also reveal insufficiency, and more clearly evidence this low level of training, independent of the type of disability in question: hearing, visual, cognitive, motor, etc. (Brodin \& Lindstrand, 2010; Vladimirovna \& Sergeevna, 2015). This has a negative repercussion on the use of ICT, preventing this information from being made more accessible and the abilities of disabled individuals being enhanced, and failing to make it easier for their difficulties to be mitigated or reduced to a minimum (Homero, Tejedor \& Calvo, 2017).

Nonetheless, in the Spanish context, in recent years there have been research studies that have addressed the problems of ICT training and education and the competencies required by teachers for their day to day practices, in order for ICT to be used with 
people with a disability (Morales \& Llorente Cejudo, 2016; Cabero, Fernández Batanero \& Barroso, 2016). Despite this, both studies analyse this need for training by focusing their attention on the initial training of teaching staff, without including active teachers and their corresponding permanent training.

For this reason, the conducting of a study that encompasses the previously-mentioned aspects is of great relevance. This study will: a) offer information in relation to social aspects, where we find processes of social discrimination and exclusion of the population with a disability that are of special concern for families, education centres or other institutions and b) will place us in a position of being able to address the factors of the efficiency and effectiveness of the pedagogical practices with ICT, as they increase communication and boost the abilities of the disabled, leading to a reduction in their limitations.

\section{Research purpose, questions and hypotheses}

The purpose of this document is to provide a general and complete view of the training and education of active Primary Education teachers in Spain, in relation to the use of ICT with students with disabilities. The general question that we seek to answer is:

Are Primary School teachers in Spain sufficiently prepared for the use and application of ICT with students with disabilities?

A series of questions and hypotheses are derived from this main question.

RQ1. Is there a relationship between the technical and didactic (teaching) training that the teachers indicate having with respect to the audiovisual, computer and internet technologies and the degree of training/knowledge that they possess for the use of ICT with people with disabilities?

Null hypothesis (H0): There are no significant differences with an alpha risk of 0.05 or less between the technical and didactic training the teachers claim to possess with respect to the audiovisual, computer and internet technologies and the degree of training/knowledge they possess for the use of ICT with subjects with disabilities.

Alternative hypothesis 1 (H1): There are significant differences with an alpha risk of 0.05 or less between the technical and didactic training the teachers claim to possess with respect to the audiovisual, computer and internet technologies and the degree of training/knowledge they possess for the use of ICT with subjects with disabilities.

RQ2. Is the level of training of the teachers the same or different depending on the type of disability: hearing, motor, visual, cognitive, etc.?

As a function of this question, the following hypotheses were formulated:

Null hypothesis 2 (H0): There are no significant differences with an alpha risk of 0.05 or less between the knowledge the teachers have on the technologies applied to the different types of disability (general, hearing, motor, visual, cognitive and accessibility).

Alternative hypothesis 2 (H1): There are significant differences with an alpha risk of 0.05 or less between the knowledge the teachers have on the technologies applied to the different types of disability (general, hearing, motor, visual, cognitive and accessibility).

RQ3. Is the level of training of the teachers determined by personal (gender, age), professional (teaching experience) or educational (university degree) variables? 
This question allows us to formulate the following hypotheses:

Null hypothesis 3-4-5-6-7-8 (H0): There are no significant differences with an alpha risk of 0.05 or less as a function of the teacher's gender (their age; their years of teaching experience; their university degree; their specialisations studied; and having received training on the use of technologies with people with disabilities), and the knowledge they possess on the use of technologies with different types of disability (general, hearing, motor, visual, cognitive and accessibility).

Alternative hypothesis 3-4-5-6-7-8 (H0): There are significant differences with an alpha risk of 0.05 or less as a function of the teacher's gender (their age; their years of teaching experience; their education degree; their specialisations studied; and having received training on the use of technologies with people with disabilities), and the knowledge they possess on the use of technologies with different types of disability (general, hearing, motor, visual, cognitive and accessibility).

\section{Method}

The design of the study was post-facto descriptive, with an accidental non-probabilistic sample.

\section{Participants}

The study sample comprised 777 teachers from primary schools from the 17 Autonomous Communities of Spain, with most of these centres being public $(\mathrm{f}=588$, $75.68 \%)$, followed by semi-private schools $(\mathrm{f}=141,18.15 \%)$ and 48 private schools $(6.18 \%)$.

Of these 777 teachers, $216(27.80 \%)$ were men and $561(72.20 \%)$ women. $25.48 \%$ $(\mathrm{f}=198)$ were under 30 years old, $27.84 \%(\mathrm{f}=294)$ were aged between 31 and 40, $30.89 \%(\mathrm{f}=240)$ were aged between 41 and 55 , and $5.79 \%(\mathrm{f}=45)$ were older than 55 years of age. A little over $35 \%(35.14 \%, \mathrm{f}=275)$ had between 1 and 5 years' teaching experience, followed by $18.15 \%$ ( $\mathrm{f}=141)$ who had between 16 and 25 years' experience.

Most of these teachers (43.24\%, $\mathrm{f}=336)$ were civil servants, followed by $19.31 \%$ $(\mathrm{f}=150)$ who were interim staff, with the smallest number of teachers being substitute teachers $(2.70 \%, \mathrm{f}=33) . \quad 258(33.20 \%)$ had a three-year degree in Primary School Teaching (General Basic Education 'EGB'), 255 (32.82\%) had a four-year university degree in Primary School Education, $51(6.56 \%)$ had a 4-year university degree in Child Education, and $213(27.41 \%)$ had other degrees.

Lastly, it should be mentioned that $219(28.19 \%)$ specialised in special education, 111 $(14.29 \%)$ in physical education, 75 (9.65\%) in English Language, $72(9.27 \%)$ in music education, and $38.61 \%(\mathrm{f}=300)$ in other specialisations.

\section{Data collection instrument}

The final version of the questionnaire comprised 71 items structured into two parts (general and specific): The general part comprised 18 items that collected information on the different biographical aspects of the teachers and information on the general evaluation of the training received on aspects related to ICT (answer option from 0 to 10 and Yes and No options). The specific part comprised 53 items, with a Likert-type response scale and six answer options, that gathered information on the following dimensions: general perception of the use of ICT with people with a disability (10 
items), ICT for people with a visual disability (9 items), ICT for people with a hearing disability (9 items), ICT for people with a motor disability ( 7 items), ICT for people with a cognitive disability (7 items).

To measure the reliability of the questionnaire, Crobach's Alpha was calculated for the entire instrument (0.993), as well as its different dimensions (general aspects scale, 0.967; visual deficiency scale, 0.986; hearing deficiency scale, 0.983; motor deficiency scale, 0.982; cognitive deficiency scale, 0.979 and accessibility scale, 0.967).

The values could be considered very high and an indication of the high levels of reliability of the scale and the dimensions this comprises (O'Dwyer \& Bernauer, 2014).

The questionnaire was published online, and can be viewed at: https://docs.google.com/forms/d/e/1FAIpQLSfux6m1cU6Nf-

69eiiMS28LjcSom38yqe2OmS-Jy4mXAgJVnA/viewform

\section{Results}

The mean score found for the entire instrument was 3.26 on a scale of 1 (very negative) to 6 (very positive), with a standard deviation of 1.28. The value obtained was above the middle value (3), which would denote that the teachers interviewed considered themselves to be regularly trained in the use of ICT with students with disabilities. This training score was higher than the general perspective (3.70) and in relation to the use of ICT with individuals with cognitive (3.45), motor (3.29) and hearing (3.02) disabilities; on the contrary, the lowest scores were found in relation to the knowledge the teachers claimed to have with respect to accessibility (2.85) and the use of technologies with people with visual disabilities (3.02).

In the general part of the questionnaire, the teachers were asked to score, using a scale of 0 to 10, the knowledge they believed they possessed with respect to the technical and educational handling of the audiovisual, computer and internet media. The results indicated that the teachers seemed to have certain knowledge with respect to the use of ICT, although usage was greater for the Internet (7.05) than for the audiovisual and computer resources (6.58), and technical handling was greater than educational handling.

a) Significance of the technical and didactic mastery of the audiovisual, computer and internet media and training on the knowledge of ICT for use with the disabled.

One of the objectives of the present research study was to understand if there was a relationship between the level of training/knowledge of the teachers on the use of ICT with students with various disabilities, and the teachers' own perspective regarding their training on the technical management and educational use of the audiovisual, computer and internet technologies. Pearson's correlation coefficient was used, with the scores shown in table 1 .

Table 1: Correlations between the technical and educational domains of the audiovisual, computer and internet media and their mastery for the educational use of ICT with students with disabilities $\left({ }^{*} p \leq .05-* * p \leq .01\right)$

\begin{tabular}{llcccc}
\hline & & & T.M. & E.M. \\
& & T.M.AV-Co & E.M.AV-Co & Int & Int \\
\hline General & Pearson's & $.106^{* *}$ & $.149^{* *}$ & $.192^{* *}$ & $.209^{* *}$ \\
& Correlation & & & & \\
\hline
\end{tabular}




\begin{tabular}{|c|c|c|c|c|c|}
\hline & Sig.(bilateral) & 0.003 & 0.000 & 0.000 & 0.000 \\
\hline \multirow[t]{2}{*}{ Visual } & $\begin{array}{l}\text { Pearson's } \\
\text { Correlation }\end{array}$ & 0.036 & $.080^{*}$ & $.099^{* * *}$ & $.111^{* * *}$ \\
\hline & Sig.(bilateral) & 0.314 & 0.026 & 0.006 & 0.002 \\
\hline \multirow[t]{2}{*}{ Hearing } & $\begin{array}{l}\text { Pearson's } \\
\text { Correlation }\end{array}$ & $.090^{*}$ & $.130^{* *}$ & $.140^{* *}$ & $.156^{* *}$ \\
\hline & Sig.(bilateral) & 0.012 & 0.000 & 0.000 & 0.000 \\
\hline \multirow[t]{2}{*}{ Motor } & $\begin{array}{l}\text { Pearson's } \\
\text { Correlation }\end{array}$ & $.072^{*}$ & $.088^{*}$ & $.111^{* * *}$ & $.101^{* *}$ \\
\hline & Sig.(bilateral) & 0.044 & 0.015 & 0.002 & 0.005 \\
\hline \multirow[t]{2}{*}{ Cognitive } & $\begin{array}{l}\text { Pearson's } \\
\text { Correlation }\end{array}$ & $.084^{*}$ & $.097^{* * *}$ & $.140^{* *}$ & $.152^{* *}$ \\
\hline & Sig.(bilateral) & 0.019 & 0.007 & 0.000 & 0.000 \\
\hline \multirow[t]{2}{*}{ Accessibility } & $\begin{array}{l}\text { Pearson's } \\
\text { Correlation }\end{array}$ & 0.053 & $.088^{*}$ & $.134^{* *}$ & $.123^{* *}$ \\
\hline & Sig.(bilateral) & 0.144 & 0.014 & 0.000 & 0.001 \\
\hline \multirow[t]{2}{*}{ Total } & $\begin{array}{l}\text { Pearson's } \\
\text { Correlation }\end{array}$ & $.079^{*}$ & $.115^{* *}$ & $.148^{* *}$ & $.156^{* * *}$ \\
\hline & Sig.(bilateral) & 0.027 & 0.001 & 0.000 & 0,000 \\
\hline
\end{tabular}

Note. T.M. AV-Co (audiovisual-computer technical mastery); E.M. AV-Co (audiovisualcomputer educational mastery); T.M. Int (Internet technical mastery); E.M. Int (Internet educational mastery).

The results were split three ways: firstly, there were primarily significant relationships between the technical and educational mastery of the audiovisual, computer and internet media, and the mastery the teachers claimed to have on the use of ICT with students with disability, in general as well as for different types; in second place, the correlations were positive, so that when one variable increased, the other also did and in the same direction; and in third place, these correlations were very low.

b) Differences in the knowledge possessed by the teachers on ICT used with different types of disability.

As for the existence of significant relationships between the knowledge mentioned by the different teachers on the different dimensions studied in the questionnaire (general, visual, hearing...etc.), a new Pearson's correlation coefficient was used, with the values shown in table 2.

Table 2: Correlations between the different dimensions in the questionnaire. $\left({ }^{*} p \leq .01\right)$

\begin{tabular}{lc}
\hline Dimensions compared & Correlation \\
\hline General-Visual & $.738^{* *}$ \\
\hline General-Hearing & $.775^{* *}$ \\
\hline General-Motor & $.744^{*}$ \\
\hline General-Cognitive & $.770^{*}$ \\
\hline General-Accessibility & $.676^{* *}$ \\
\hline Visual-Hearing & $.814^{* *}$ \\
\hline Visual-Motor & $.804^{*}$ \\
\hline Visual-Cognitive & $.742^{*}$ \\
\hline Visual-Accessibility & $.773^{*}$ \\
\hline Hearing-Motor & $.865^{*}$ \\
\hline
\end{tabular}




\begin{tabular}{ll}
\hline Hearing-Cognitive & $.832 * *$ \\
\hline Hearing -Accessibility & $.753 * *$ \\
\hline Motor-Cognitive & $.837 *$ \\
\hline Motor-Accessibility & $.774 * *$ \\
\hline Cognitive-Accessibility & $.728 * *$ \\
\hline
\end{tabular}

In this case, the results showed that all the correlations were positive and significant to ** $\mathrm{p} \leq .001$, and very high. In other words, the teachers who indicated that they had been trained in one of the dimensions were also trained in the others.

In order to analyse the hypothesis that referred to possible significant differences with an alpha risk of 0.05 or less between the knowledge the teachers have of the technologies applied to the different types of disability (general, hearing, motor, visual, cognitive and accessibility), a Student's t-test was used, which resulted in the values for 776 degrees of freedom are shown in table 3.

Table 3: Student's t-test values between the different dimensions examined in the questionnaire. $(* * p \leq .01)$

\begin{tabular}{lc}
\hline Dimensions compared & $t$ \\
\hline General-Visual & $19.529^{* *}$ \\
\hline General-Hearing & $14.617^{* *}$ \\
\hline General-Motor & $10.846^{* *}$ \\
\hline General-Cognitive & $6.855^{* *}$ \\
\hline General-Accessibility & $21.973^{* *}$ \\
\hline Visual-Hearing & $-5.766^{* *}$ \\
\hline Visual-Motor & $-8.164^{* *}$ \\
\hline Visual-Cognitive & $-11.349^{* *}$ \\
\hline Visual-Accessibility & $5.028^{* *}$ \\
\hline Hearing-Motor & $-3.170^{* *}$ \\
\hline Hearing-Cognitive & $-7.952^{* *}$ \\
\hline Hearing - Accessibility & $9.683^{* *}$ \\
\hline Motor-Cognitive & $-5.093^{* *}$ \\
\hline Motor-Accessibility & $12.375^{* *}$ \\
\hline Cognitive- Accessibility & $15.380^{* *}$ \\
\hline
\end{tabular}

The resulting values led to the rejection of all the $\mathrm{H} 0$ to conclude that there were statistically significant differences as well as an alpha risk of $p \leq .001$ with respect to the knowledge shown by the teachers on the different types of knowledge of the use of ICT with individuals with different types of disabilities.

c) Differences in the knowledge possessed by the teachers on ICT used with different types of disabilities as a function of gender.

Another of the hypotheses referred to the existence of differences in the knowledge possessed as a function of the gender of the 216 male and the 561 female teachers, with the mean values shown in table 4.

Table 4: Values found as a function of the teachers' gender 


\begin{tabular}{lll}
\hline & Gender & Mean \\
\hline General & Male & 3.6000 \\
\cline { 2 - 3 } & Female & 3.7326 \\
\hline Visual & Male & 2.8356 \\
\cline { 2 - 3 } & Female & 3.0914 \\
\hline \multirow{2}{*}{ Hearing } & Male & 2.8920 \\
\cline { 2 - 3 } & Female & 3.3244 \\
\hline Motor & Male & 3.2560 \\
\cline { 2 - 3 } & Female & 3.3086 \\
\hline Cognitive & Male & 3.1337 \\
\cline { 2 - 3 } & Female & 3.5782 \\
\hline Accessibility & Male & 2.8869 \\
\cline { 2 - 3 } & Female & 2.8304 \\
\hline Total & Male & 3.0967 \\
\cline { 2 - 3 } & Female & 3.3196 \\
\hline
\end{tabular}

As shown by the mean values, they tended to be higher for the women than for the men, except for the "accessibility" dimension.

In order to analyse if the differences found were significant from a statistical point of view, a Student's t-test was used for independent samples, although prior to this, a Levene's test was used to analyse the homogeneity of the variances (homoscedasticity), and as a function of the significance value obtained, to determine the t-value that should be used. Table 5 shows the values obtained and the degree of significance used to accept or reject the H0, which referred to the non-existence of significant differences.

Table 5: Differences as a function of the gender of the teachers. (** $p \leq .01)$

\begin{tabular}{|c|c|c|c|c|c|}
\hline & & \multicolumn{4}{|c|}{$\begin{array}{c}\text { Levene's } \\
\text { test }\end{array}$} \\
\hline & & $F$ & Sig. & $D f$ & Sig. \\
\hline \multirow[t]{2}{*}{ General } & Equal variances are assumed & 1.582 & .209 & $-1.447 \quad 775$ & .148 \\
\hline & $\begin{array}{l}\text { Equal variances are not } \\
\text { assumed }\end{array}$ & & & -1.500420 .348 & .134 \\
\hline \multirow[t]{2}{*}{ Visual } & Equal variances are assumed & 20.998 & .000 & $-2.253 \quad 775$ & .025 \\
\hline & $\begin{array}{l}\text { Equal variances are not } \\
\text { assumed }\end{array}$ & & & -2.459472 .723 & $.014 * *$ \\
\hline \multirow[t]{2}{*}{ Hearing } & Equal variances are assumed & 8.248 & .004 & $-3.667 \quad 775$ & .000 \\
\hline & $\begin{array}{l}\text { Equal variances are not } \\
\text { assumed }\end{array}$ & & & -3.898444 .653 & $.000 * *$ \\
\hline \multirow[t]{2}{*}{ Motor } & Equal variances are assumed & 3.106 & .078 & $-.426 \quad 775$ & .670 \\
\hline & $\begin{array}{l}\text { Equal variances are not } \\
\text { assumed }\end{array}$ & & & -.441420 .314 & .659 \\
\hline \multirow[t]{2}{*}{ Cognitive } & Equal variances are assumed & .618 & .432 & -3.641 & .000 \\
\hline & $\begin{array}{l}\text { Equal variances are not } \\
\text { assumed }\end{array}$ & & & -3.702403 .679 & $.000 * *$ \\
\hline \multirow[t]{2}{*}{ Accessibili } & Equal variances are assumed & 6.028 & .014 & .488 & .626 \\
\hline & $\begin{array}{l}\text { Equal variances are not } \\
\text { assumed }\end{array}$ & & & .519445 .475 & .604 \\
\hline
\end{tabular}




\begin{tabular}{|c|c|c|c|c|c|}
\hline \multirow[t]{2}{*}{ Total } & Equal variances are assumed & 7.550 & $.006-2.181$ & 775 & $.029 * *$ \\
\hline & $\begin{array}{l}\text { Equal variances are not } \\
\text { assumed }\end{array}$ & & -2.326 & 749 & .020 \\
\hline
\end{tabular}

The results did not lead to the rejection of the $\mathrm{H} 0$ that referred to the non-existence of statistically-significant differences to $p \leq .05$ or less in the following dimensions: general knowledge, application of ICT with people with motor and accessibility deficits. On the other hand, there were significant differences in the following dimensions: visual, hearing and cognitive. It should be mentioned that the $\mathrm{H} 0$ was also rejected due to the scores found for the instrument as a whole. In every case, the female teachers had greater knowledge than the men on the use of ICT with people with disabilities.

d) Differences in the knowledge possessed by the teachers on ICT used with different types of disabilities as a function of age.

An ANOVA was used to analyse if there were statistically-significant differences as a function of the teachers' age. It should be noted that as the procedure followed was explained previously, only the $\mathrm{F}$ values obtained will be presented, as well as the degree of significance, which were as follows: General $(\mathrm{F}=18.059 ; \mathrm{p} \leq 0.001)$, visual $(\mathrm{F}=14.656 ; \mathrm{p} \leq 0.001)$, hearing $(\mathrm{F}=24.070 ; \mathrm{p} \leq 0.001)$, motor $(\mathrm{F}=21.786 ; \mathrm{p} \leq 0.001)$, cognitive $(\mathrm{F}=22.790 ; \mathrm{p} \leq 0.001)$ accessibility $(\mathrm{F}=7.732 ; \mathrm{p} \leq 0.001)$, and total $(\mathrm{F}=20.591$; $\mathrm{p} \leq 0.001)$.

The results allowed for the rejection of all the $\mathrm{H} 0$ formulated that referred to the nonexistence of significant differences as a function of the teachers' age, to a significance level of $\mathrm{p} \leq .01$, with respect to the knowledge the teachers mentioned having on the use of ICT with individuals with disabilities. These differences were found in their general knowledge, as well as their knowledge of the different types of diversity.

In order to understand if there were differences between the different age groups, a "Post-Hoc" ANOVA analysis was applied for multiple comparisons (Miller, 1997). It should be noted that in order to avoid over-analysing the results, and as the results were very similar, it could be said that the differences were mainly found between the younger teachers with respect to those who were older. As a result, it could be indicated that the 10-year age range was sufficient to establish differences in the knowledge the teachers indicated having on the use of ICT with students with disabilities.

e) Differences in the knowledge the teachers have on ICT taught to people with different types of disability as a function of their years' experience.

In order to analyse the existence of possible differences as a function of years' teaching experience, a new ANOVA was performed which resulted in the following: General $(F=8.350 ; p \leq 0.001)$, visual $(F=7.491 ; p \leq 0.001)$, hearing $F=15.450 ; p \leq 0.001)$, motor $(\mathrm{F}=12.410 ; \mathrm{p} \leq 0.001)$, cognitive $(\mathrm{F}=12.048 ; \mathrm{p} \leq 0.001)$, accessibility $(\mathrm{F}=2.183 ; \mathrm{p} \leq$ $0.001)$, and total $(\mathrm{F}=10.926 ; \mathrm{p} \leq 0.001)$. The results point to the existence of significant differences with an alpha risk of $\mathrm{p} \leq 0.01$, as a function of the years' teaching experience.

f) Differences in the knowledge the teachers have on ICT taught to people with different types of disability as a function of their academic degrees.

As regards the differences in the teachers' knowledge of the technologies as a function of their academic degree (4-year degree in Primary School Teaching, 4-year degree in 
Child Education, 3-year in Primary School Education, and others), and after the performance of an ANOVA, the results were as follows: general $(\mathrm{F}=13.465 ; \mathrm{p} \leq 0.001)$, visual $(\mathrm{F}=19.772 ; \mathrm{p} \leq 0.001)$, hearing $(\mathrm{F}=17.493 ; \mathrm{p} \leq 0.001)$, motor $(\mathrm{F}=17.367 ; \mathrm{p} \leq$ $0.001)$, cognitive $(\mathrm{F}=9.605 ; \mathrm{p} \leq 0.001)$, accessibility $(\mathrm{F}=6.044 ; \mathrm{p} \leq 0.001)$, and total $(\mathrm{F}=16.467 ; \mathrm{p} \leq 0.001)$. These results allowed us to reject the $\mathrm{H} 0$, thereby confirming that there were significant differences at a level of $\mathrm{p} \leq 0.05$ between the different working conditions and the knowledge shown, in a general sense as well as for the different dimensions covered in the questionnaire.

The application once again of the "post-hoc" statistical test for multiple comparisons allowed the highlighting of the fact that the fundamental differences found were between the teachers with a 3-year degree in primary school teaching ('Bachelor's Degree') and the rest of the teachers; the latter were the ones who mentioned having more knowledge with respect to the use of ICT with students with disabilities.

g) Differences in the knowledge the teachers have on ICT applied to different types of disability as a function of their specialisations studied.

We also wanted to verify if there were significant differences between the different specialisations studied by the teachers and the knowledge shown. The following values were found after the ANOVA: general $(\mathrm{F}=11.932 ; \mathrm{p} \leq 0.001)$, visual $(\mathrm{F}=11.598 ; \mathrm{p} \leq$ $0.001)$, hearing $(\mathrm{F}=18.139 ; \mathrm{p} \leq 0.001)$, motor $(\mathrm{F}=16.996 ; \mathrm{p} \leq 0.001)$, cognitive $(\mathrm{F}=16.012 ; \mathrm{p} \leq 0.001)$, accessibility $(\mathrm{F}=2.747 ; \mathrm{p} \leq 0.05)$, and total $(\mathrm{F}=15.058 ; \mathrm{p} \leq 0.001)$. These results allow us to reject the $\mathrm{H} 0$ and conclude that there were significant differences between the different specialisations and the knowledge shown, in a general sense as well as in the different dimensions studied in the questionnaire, with a level of significance of $\mathrm{p} \leq 0.001$.

After applying the "post-hoc" statistical test for multiple comparisons, it was concluded, as expected, that the teachers who had taken courses to specialise in "special education" indicated that they possessed more knowledge than the rest of the teachers. Amongst the different types of specialisation studied and the knowledge shown by the teachers on the use of ICT with individuals with disabilities, the teachers who had taken courses for the "physical education" specialisation had the least knowledge.

h) Differences in the knowledge the teachers possessed on ICT taught to people with different types of disability as a function of receiving training with respect to the educational use of ICT.

The last hypothesis was aimed at understanding if, throughout their teaching career, the teachers had received information with respect to the use of ICT with individuals with a disability and on design and accessibility. Most of the teachers mentioned not having received any information, neither in relation to the use of ICT with individuals with a disability (66.12\%), nor to that referring to accessibility and accessible design (64.48\%).

With the aim of determining if receiving training with respect to the educational use of ICT with people with a disability had an effect on the knowledge they claimed they possessed for the use of ICT with people with disabilities and the knowledge on accessibility, a Student's t-test was used. The following results were obtained: In first place: General $(\mathrm{t}=9.937 ; \mathrm{p} \leq 0.001)$, visual $(\mathrm{t}=7.213 ; \mathrm{p} \leq 0.001)$, hearing $(\mathrm{t}=5.487 ; \mathrm{p} \leq$ $0.001)$, motor $(\mathrm{t}=6.932 ; \mathrm{p} \leq 0.001)$, cognitive $(\mathrm{t}=7.787 ; \mathrm{p} \leq 0.001)$, accessibility $(\mathrm{t}=4.242$; $\mathrm{p} \leq 0.05)$, and total $(\mathrm{t}=7.737 ; \mathrm{p} \leq 0.001)$, and in the second case, accessibility, the following values were found: general $(t=3.882 ; \mathrm{p} \leq 0.001)$, visual $(\mathrm{t}=-0.255 ; \mathrm{p}=0.799)$, 
hearing $(\mathrm{t}=0.528 ; \mathrm{p}=0.597)$, motor $(\mathrm{t}=-1.062 ; \mathrm{p}=0.289)$, cognitive $(\mathrm{t}=1.720 ; \mathrm{p}=0.086)$, accessibility $(\mathrm{t}=-0.878 ; \mathrm{p}=0.381)$, and total $(\mathrm{t}=0.707 ; \mathrm{p}=0.480)$.

The results allow us to conclude that having received information with respect to the use of ICT with individuals with disabilities had an effect on the teachers' knowledge shown on the educational use of these tools with students with functional diversity, although these results were not the same for the information received on accessible design and accessibility.

\section{Discussion and conclusions}

The results presented contribute to the debate between the potential of ICT for the improvement of the teaching-learning processes of students with disabilities and the teacher training needed to carry out said processes.

With respect to the general question of the study, it should be noted that there was a lack of training amongst Spanish primary education teachers in the use and application of ICT with disabled students. These findings are similar to those obtained in previous research studies, in both the Spanish and international context (Brodin \& Lindstrand 2010; Shin, 2015 y Hatlevik, 2017). This clearly denotes the need to promote education policies on the initial and ongoing training of teachers on the use of ICT with individuals with disabilities. In this sense, we believe that there is a need to adopt urgent measures to train teachers so they can incorporate ICT into their daily work with people with different types of disability. Thus, specific training is required including knowledge on materials, software and websites that favour the application of strategies and adaptations, training that takes into account accessibility criteria for the development of educational materials and which facilitates the creation of learning environments in accordance with the everyday reality of the centres, the teachers' demands and mainly, the students' characteristics.

On the other hand, the study brings to light the fact that the deficits in knowledge are found in a similar manner for every type of disability analysed, for which reason the action taken should be general in nature as well as specific, catering to all the diversities that might be found.

RQ1. Is there any relationship between the technical and didactic (teaching) training the teachers indicate having with respect to the audiovisual, computer and internet technologies and the degree of training/knowledge they possess for the use of ICT with people with disabilities?

The teachers strongly agreed that ICT were a useful resource for the training of people with disabilities. However, the technical handling and educational use they mentioned having in ICT, computers and the Internet had an effect on the knowledge they claimed to possess for the use of these technologies with people with disabilities. Thus, as already mentioned, didactic training is needed to teach them to use ICT to favour learning and education innovation with this type of student. This is where the need arises for study plans to include double-level courses, on the one hand, in relation to the educational application of ICT within the context of training, and on the other, the addition of specific courses aimed at the analysis of the educational possibilities of ICT with people with disabilities.

RQ2. Is the teachers' level of training the same or different depending on the types of disability: hearing, motor, visual, cognitive,...? 
The low level of training mentioned was found to exist to a greater extent in the specific inclusion of the technologies in the learning processes of students with disabilities: visual, hearing, motor and cognitive, as well as in relation to accessible design and accessibility; without different levels of training detected between them, for which reason the training options should be generalised for all of them. These aspects coincided with studies such as the one by Suriá, Martínez and Ordoñez (2010). This low level of training could make the complete inclusion of students with different types of disability difficult, even more where it is the school's responsibility to create a stage, both analogical and digital, that facilitates a person's inclusion. As a result, the education centres and teacher training centres should promote this training, with three methods highlighted: a) the creation of courses, seminars, etc., b) the conducting of meetings where teachers are informed about the activities published, where information and knowledge on the subject are shared, or where "new practices" on the addition of ICT for students with diversities are presented; and c) the addition of ICT in the teacher training with courses over the internet, using either e-learning or MOOC methods.

RQ3. Is the teachers' level of training determined by personal (gender, age), professional (teaching experience) or educational (university degree) variables?

The teachers had different levels of competency, where the female teachers perceived themselves as having more knowledge than the male teachers, a result that has not appeared in other studies such as the one by Ilomäki (2011), where this difference leaned in favour of the male teachers. These results start to coincide with other studies, where the results generally indicated that the female teachers had greater digital competency for the use of ICT than the male teachers (Lohbeck, Hagenauer, \& Frenzel, 2018; Güdüz \& İşman, 2018); in other words, the gender-based digital divide between teachers is decreasing or has disappeared.

The teachers' age and their years' experience had an effect on the level of knowledge on ICT used with people with disabilities. In this sense, in both cases the younger students indicated having more knowledge. Previous research has already confirmed these findings (Alqurashi, Gokbeli \& Carbonara, 2016; Gudmundsdottir \& Hatlevik, (2017). This could be explained by the younger teachers being closer to the end of their studies, and the recent addition to the curriculum of training elements on the use of ICT with people with disabilities.

To a certain degree, and in relation to the above, by age, those who had received a 4year degree felt they had more knowledge than those who had received a three-year degree in General Basic Education Teaching. This leads us to suggest a curricular restructuring for teacher training in Spain, which, since the disappearance of specialisations, has provided the students with a more generalised knowledge that may have negative repercussions on the practical needs of the training activities.

The results found also point to individual efforts carried out by the teachers to supplement the lack of initial training with experience.

As for the limitations of this research study, we can highlight three: a) it is an exploratory study, and in order to verify the results, research studies using stratified samples according to provinces and autonomous communities should be conducted, b) the instrument used allowed us to obtain the self-perceptions of the teachers who completed the questionnaire, and confirmation thereof would require the combined use of another type of data-gathering instrument such as observation and in-depth interviews; and c) information was gathered exclusively about the teachers, and it would 
be convenient to obtain information about those who are responsible for the centres and the perceptions of the teacher training centre directors regarding the training aspects of the teachers.

As future lines of research, we propose: the conducting of studies on good practices for the incorporation of ICT with people with disability, using data-collecting techniques such as non-participating observation and in-depth interviews; the increasing of the sample of informants through the addition of centre directors, those responsible for the teacher training and the students' parents; and the expansion on specific problems the teachers have in using ICT with subjects with disabilities.

\section{Acknowledgements}

The work was financed by the Spanish Ministry of Economics and Competitiveness within the State Plan for the Development of Scientific and Technical Research of Excellence 2013-2016 (DIFOTICYD EDU2016 75232-P).

\section{Statements on open data, ethics and conflicts of interest}

The data described in this article contains no personal, or personally identifiable information and is not accessible to other researchers as per written agreement with the participants and ethical approval. There is no conflict of interest regarding this work.

\section{References}

Alqurashi, E., Gokbel, E. N. \& Carbonara, D. (2017). Teachers' knowledge in content, pedagogy and technology integration: A comparative analysis between teachers in Saudi Arabia and United States. British Journal of Educational Technology, 48, 1414-1426. doi:10.1111/bjet.12514

Brodin, J. \& Lindstrand, P. (2010). What about ICT in special education? Special educators evaluate information and communication technology as a learning tool. European Journal of Special Needs Education, 71-87. doi: https://doi.org/10.1080/0885625032000042320

Cabero, J. \& Martín, V. (2014). Views on teacher training on information and communications technologies (ICT). Enl@ace: Revista Venezolana de Información, Tecnología y Conocimiento, 11(2), 11-24.

Cabero, J., Fernández Batanero, J. M. \& Barroso, O. (2016). Students of the Teaching degree: ICT and disability. Revista Electrónica de Investigación Educativa, 18(3), 106-120. Retrieved from http://redie.uabc.mx/redie/article/view/965

Cappuccio, G., Compagno, G. \& Pedone, F. (2016). Digital Competence for the improvement of Special Education Teaching. Journal of e-Learning and Knowledge Society, 12(4), 93-108.

Ghaleb, A. (2014). Assistive technology in special education and the universal design for learning. TOJET: the Turkish online Journal of Educational Technology, 13 (2), 18-23.

Gudmundsdottir, G. B. \& Hatlevik, O. E. (2017). Newly qualified teachers' professional digital competence: implications for teacher education. European Journal of Teacher Education, 41(2), 214-231. doi: 10.1080/02619768.2017.1416085

Güdüz, A. \& İşman, A. (2018). Pre-Service Teachers' Perception of Distance Education. TOJET: The Turkish Online Journal of Educational Technology, $17(1), 125-129$. 
Hatlevik, O. E. (2017). Examining the Relationship between Teachers' Self-Efficacy, their Digital Competence, Strategies to Evaluate Information, and use of ICT at School. Scandinavian Journal of Educational Research, 61(5), 555-567.

Hersh, M. (2016). Classification framework for ICT-based learning technologies for disabled people. British Journal of Educational Technology, 768-788. doi: https://doi.org/10.1111/bjet.12461

Homero, G., Tejedor, F. J. \& Calvo, M. I. (2017). Meta-analysis on the effect of education software on students with special education needs. Revista de Investigación Educativa, 35(1), 35-52.

Hu, X. \& Yelland, N. (2017). An Investigation of preservice early childhood teachers' adoption of ICT in a teaching practicum context in Hong Kong. Jounal of Early Childhood Teacher Education, 38(3), 257-274.

Ilomäki, L. (2011). Does Gender Have a Role in ICT Among Finnish Teachers and Students? Scandinavian Journal of Educational Research, 55(3), 325-340. Doi: $10.1080 / 00313831.2011 .576910$

Istenic, A \& Bagon, S. (2013). ICT-supported learning for inclusion of people with special needs: Review of seven educational technology journals, 1970-2011. British Journal of Educational Technology, 45(2), 202-230. doi: https://doi.org/10.1111/bjet.12086

Lohbeck, A., Hagenauer, G., \& Frenzel, A. C. (2018). Teachers' self-concepts and emotions: Conceptualization and relations. Teaching and Teacher Education, 70, 111-120.

Miller, R. G. (1997). Beyond ANOVA: Basics of applied statistics. CRC Press.

Morales, P. T. \& Llorente Cejudo, M. C. (2016). Initial training of the teaching staff on the use of Information and Communication Technologies (ICT) for the education of the disabled. Digital Education Review, 30, 123-134.

O'Dwyer, L. \& Bernauer, J. (2014). Quantitative Research for the Qualitative Researcher. California: Sage.

Shin, W. S. (2015). Teachers' use of technology and its influencing factors in Korean elementary schools. Technology, Pedagogy and Education, 24, 461-476. doi:10.1080/1475939x.2014.915229.

Suárez, J., Almerich, G., Gargallo, B. \& Aliaga, F. (2013). Teacher's competencies on ICT: basic structure. Educación XX1, 16(1), 39-62.

Suriá, R., Martínez, D. \& Ordoñez, T. (2010). ICT, teaching and disability: do teachers feel prepared to support disabled students in the use of ICT in the classroom? In Arnaiz, P.; Hurtado, Ma. D. y Soto, F. J. (Coords.) 25 Años de Integración Escolar en España: Tecnología e Inclusión en el ámbito educativo, laboral y comunitario. Murcia: Consejería de Educación, Formación y Empleo.

Tello, I. \& Cascales, A. (2015). ICT and specific needs for educational support: analysis of teachers' ICT competences. RIED, 18(2), 355-383.

Vladimirovna, S. \& Sergeevna, O. (2015). Features of the Information and Communication Technology Application by the Subjects of Special Education. International Education Studies; 8 (6), doi:10.5539/ies.v8n6p162, recuperado de http://www.ccsenet.org/journal/index.php/ies/article/view/49385 